\title{
Implementasi Kebijakan Bantuan Pangan Non-Tunai Melalui Elektronik Warung Gotong Royong (E-Warong) di Kecamatan Subang Kabupaten Subang
}

\author{
Tony Pathony ${ }^{1}$ \\ Fakultas Ilmu Administrasi Universitas Subang \\ tonypathony.jurnal@gmail.com
}

Cornelis Deda ${ }^{2}$

STFT GKI I.S. Kijne Jayapura

corbath58@gmail.com

\begin{abstract}
Abstrak
Hasil penelitian menunjukan bahwa sasaran kebijakan dalam pelaksanaannya belum tepat sasaran dalam pemilihan pemilik E-Warong, Seluruh pemilik E-Warong di Kecamatan Subang bukan berasal dari penerima manfaat Bantuan Sosial melainkan berasal dari agenbrilink yang sudah ada. Sumber daya diketahui bahwa kelengkapan sarana dan prasarana masih belum memadai dan menghambat pada pengimplementasian kebijakan Bantuan Pangan Non Tunai melalui E-Warong. Masih perlu adanya penambahan E-Warong sebagai sarana dan prasarana dalam kebijakan ini, agar tidak terjadi penumpukan KPM di 10 E-Warong yang ada di Kecamatan Subang. Komunikasi antara Kecamatan Subang dengan Dinas Sosial dalam menentukan persyaratan dan kriteria E-Warong belum berjalan optimal.

Kata Kunci : Implementasi Kebijakan
\end{abstract}

Kata Kunci : Implementasi, Kebijakan, E-Warong,

\section{Abstract}

The results showed that the policy target in its implementation was not yet right in the selection of E-Warong owners. All E-Warong owners in Subang District did not come from the Social Assistance beneficiaries but instead came from existingbrilink agents. Resources are known that the completeness of facilities and infrastructure is still inadequate and hinders the implementation of the Non-Cash Food Assistance policy through E-Warong. There is still a need to add E-Warong as a means and infrastructure in this policy, so there is no accumulation of KPM in 10 E-Warong in Subang District. Communication between Subang District and the Social Service in determining the requirements and criteria for E-Warong has not been optimal.

Keywords : Policy, Implementation, E-Warong 


\section{Pendahuluan}

Kemiskinan merupakan salah satu persoalan yang menjadi pusat perhatian di negara manapun. Kemiskinan merupakan gambaran kehidupan di banyak negara berkembang yang diartikan sebagai ketidakmampuan dalam hal ekonomi. Namun bukan hanya ketidakmampuan ekonomi saja, melainkan kemiskinan terjadi karena kegagalan untuk memenuhi kebutuhan dasar dari masing-masing individu dalam kehidupan sehari-hari. Kemiskinan telah membuat jutaan anak tidak bisa mengenyam pendidikan, kesulitan membiayai kesehatan dan masalah lain yang menjurus ke arah tindakan kekerasan dan kejahatan. Kemiskinan yang terjadi dalam suatu negara memang perlu dilihat sebagai suatu masalah yang sangat serius, karena saat ini kemiskinaan membuat banyak masyarakat Indonesia mengalami kesusahan dalam memenuhi kebutuhan hidupnya. Hal ini, karena masyarakat miskin cenderung memiliki pendidikan yang sangat rendah, sehingga tidak mampu bersaing yang pada akhirnya menjadi pengangguran. Salah satu kota yang masih memiliki permasalahan mengenai kemiskinan yaitu kota Subang. Salah satu program yang dibentuk oleh pemerintah untuk mengurangi beban masyarakat dalam pemenuhan kebutuhan pokok adalah Program Bantuan Pangan Non Tunai (BPNT). Program BPNT adalah bantuan pangan yang disalurkan secara non tunai dari pemerintah kepada Keluarga Penerima Manfaat (KPM) setiap bulan, melalui mekanisme akun elektronik yang digunakannya untuk membeli bahan pangan di tempat yang bekerjasama dengan Bank Himbara. Program BPNT diselenggarakan oleh pemerintah, dalam rangka untuk meningkatkan efektivitas dan efisiensi, ketepatan sasaran penyaluran bantuan sosial serta mendorong keuangan inklusif. Untuk mendorong pelaksanaan program BPNT, maka Presiden Republik Indonesia telah menetapkan Peraturan Presiden Republik Indonesia Nomor 63 tahun 2017, tentang Penyaluran Bantuan Sosial Secara Non Tunai. Presiden sangat mengapresiasi program BPNT, karena mampu mengurangi beban pengeluaran KPM melalui pemenuhan sebagian kebutuhan pangan, memberikan gizi yang seimbang kepada peserta KPM, meningkatkan ketepatan sasaran dan waktu penerimaan bantuan pangan serta mendorong kearah pembangunan yang berkelanjutan.

Untuk mengoptimalkan penyaluran bantuan sosial, maka Kementrian Sosial telah mengeluarkan Peraturan Menteri Sosial Republik Indonesia Nomor 25 Tahun 2016, tentang Bantuan Pengembangan Usaha Melalui Elektronik Warung Gotong Royong atau disingkat E-Warong. E-Warong adalah sarana usaha dalam pencairan bantuan sosial berupa bahan pangan pokok dan/atau uang tunai secara elektronik dan merupakan sarana pembayaran yang dilaksanakan secara elektronik/non tunai, sehingga mempermudah dalam penerimaan bantuan program Bantuan Pangan Non Tunai (BPNT). Penyaluran Bantuan Pangan Non Tunai dilaksanakan melalui sistem perbankan untuk mendukung perilaku produktif masyarakat melalui fleksibilitas waktu penarikan bantuan dan akumulasi aset melalui kesempatan menabung. Pada akhirnya,penyaluran Bantuan Pangan Non Tunai diharapkan memberi dampak bagi peningkatan kesejahteraan dan kemampuan ekonomi penerima manfaat melalui akses yang lebih luas terhadap layanan keuangan. Pelaksanaan penyaluran Bantuan Pangan Non Tunai dibantu oleh perbankan yang 
menjadi agen penyalur bantuan. Selanjutnya, untuk mendukung pengelolaan elektronik warung, maka Kementerian Sosial telah bekerjasama dengan HIMBARA (Himpunan Bank-bank Negara) seperti Bank BNI, BRI, BTN dan Mandiri.

Dalam pembentukan E-Warong diawali dengan penentuan lokasi terlebih dahulu (desa, kecamatan pada setiap kabupaten). Setelah lokasi terpilih lalu dilakukan validasi terhadap penerima manfaat Bantuan Sosial yang produktif untuk dijadikan pengurus E-Warong dari KUBE Jasa, setelah itu dilakukan bimbingan teknis kepada yang tervalidasi untuk menetapkan kepengurusan. Tempat untuk mendirikan E-Warong harus bertempat di rumah salah satu pengurus atau tempat lain berdasarkan kesepakatan anggota. Kesediaan rumah untuk digunakan sebagai tempat E-Warong paling singkat 2 tahun dan dapat diperpanjang sesuai kesepakatan serta tidak menuntut biaya sewa atau biaya lainnya atas penggunaan rumah sebagai tempat E-Warong. Serta jumlah KPM Bantuan Pangan Non Tunai yang dilayani oleh E-Warong paling banyak $250 \mathrm{KPM}$.

Setelah E-Warong dan penerima bantuan sudah ditetapkan, maka dilanjutkan dengan penyaluran dana bantuan yang meliputi:

a) Bantuan Sosial KUBE Jasa Rp.20.000.000 berupa modal usaha dan modal kerja. Pemanfaatan bantuan permodalan ini $25 \%$ pembelian bahan pangan pokok dan $75 \%$ modal kerja mendukung usaha sesuai dengan kebutuhan prioritas seperti pembelian listrik, timbangan barang, mesin pengemas hampa udara, lemari pendingin dan pengangkut barang.

b) Dalam hal sisa dari pembelian modal kerja atau belum digunakan untuk pembelian modal kerja, harus dimanfaatkan untuk modal usaha.

c) Bantuan pengembangan sarana usaha sebesar Rp.10.000.000 untuk rehabilitasi ruangan, pengadaan lemari etalase dan rak tempat barang.

Menurut Basis Data Terpadu (BDT) Kabupaten Subang, bahwa jumlah penerima Bantuan Pangan Non Tunai di Kabupaten Subang sebesar 112.821 KPM yang terbagi di 30 kecamatan di Kabupaten Subang. Dari 30 Kecamatan tersebut, jumlah penerima Bantuan Pangan Non Tunai di Kecamatan Subang menjadi yang terbesar dalam jumlah penerima Bantuan Pangan Non Tunai. Berdasarkan Basis Data Terpadu (BDT) Kecamatan Subang, jumlah penerima Bantuan Pangan Non Tunai di Kecamatan Subang mencapai 7.003 KPM, yang terdapat di Kelurahan Cigadung 1.015 KPM, Kelurahan Karang Anyar 1.257 KPM, Kelurahan Soklat 908 KPM, Kelurahan Pasirkareumbi 1070 KPM, Kelurahan Dangdeur 883 KPM, Kelurahan Parung 615 KPM, Kelurahan Sukamelang 774 KPM, dan Kelurahan Wanareja 481 KPM. Untuk mengoptimalkan penyaluran BPNT di Kabupaten Subang, Dinas Sosial telah bekerjasama dengan Bank BRI dalam mendukung pengelolaan elektronik warung. Dalam melakukan transaksi, peserta yang dapat mencairkan dana tersebut adalah mereka yang telah memiliki KKS elektronik. Kecamatan Subang menjadi salah satu kecamatan dengan didirikannya E-warong ini. Sebanyak 23 elektronik warung didirikan di Kecamatan Subang. Didirikannya elektronik warung ini sekaligus terlaksananya Program Bantuan Pangan Non Tunai (BPNT).

Dalam pelaksanaannya, Program Bantuan Pangan Non Tunai di Kecamatan Subang masih memiliki masalah, hal tersebut dikarenakan masih adanya penumpukan KPM pada saat pengambilan bantuan yang dilakukan di E-Warong. 10 E-Warong di Kecamatan Subang melebihi batas pelayanan KPM Bantuan Pangan 
Non Tunai, sehingga dapat menghambat pada saat transaksi dilakukan di EWarong. Untuk menghindari kejadian tersebut maka sehari sebelum pengambilan, KPM yang melakukan transaksi di 10 E-Warong yang melebihi pelayanan selalu menggesakan Kartu Keluarga Sejahtera pada malam hari kemudian pada ke esokan harinya KPM dapat mengambil Bantuan Pangan Non Tunai. Disamping masih adanya penumpukan KPM di 10 E-Warong, seluruh pemilik E-Warong di Kecamatan Subang tidak sesuai dengan kriteria dan persyaratan yang terdapat pada pedoman umum BPNT dan peraturan perundang-undangan.

Dari hasil penelitian yang dilakukan oleh peneliti, bahwa program Bantuan Pangan Non Tunai yang disalurkan melalui Elektonik Warung Gotong Royong (EWarong) yang berada di Kecamatan Subang masih belum optimal: Program Bantuan Pangan Non Tunai yang disalurkan melalui 23 E-warong di Kecamatan Subang, 10 E-warong melebihi batas jumlah pelayanan Keluarga Penerima Manfaat (KPM); kemudian dari 23 E-warong di Kecamatan Subang, seluruh pemilik E-warong bukan berasal dari penerima manfaat Bantuan Sosial.

\section{Kerangka Teori}

\section{a. Kebijakan Publik}

Secara etimologi, istilah "Kebijakan" atau "policy" digunakan untuk untuk menunjukan perilaku seorang aktor (misalnya seorang pejabat, suatu kelompok, maupun suatu lembaga pemerintah) atau suatu bidang dalam kegiatan tertentu (Rusli, 2013:31). Menurut Jefkins (dalam Rusli, 2013:33) menyarankan bahwa kebijakan hendaknya dipahami sebagai "serangkaian keputusan-keputusan yang saling terkait berkenaan dengan penilaian tujuantujuan dan cara-cara untuk mencapainya dalam situasi tertentu". Sedangkan menurut Freidrich (dalam Rusli, 2013 :33) mengatakan bahwa kebijakan adalah: "Suatu tindakan yang diusulkan pada seseorang, golongan/pemerintah dalam suatu lingkungan dengan halangan-halangan dan tantangan-tantangan yang diharapkan dapat memenuhi dan mengatasi halangan tersebut dalam rangka mencapai suatu cita-cita/mewujudkan suatu kehendak serta tujuan tersebut". Mengenai pengertian kebijakan publik, banyak para ahli-ahli kebijakan yang memberikan pendapatnya masingmasing mengenai definisi kebijakan publik yang semua benar dan saling melengkapi. Menurut Dunn (2013:132) menyebutkan istilah Kebijakan Publik (Public Policy) sebagai: "Pola ketergantungan yang kompleks dari pilihanpilihan kolektif yang saling tergantung, termasuk keputusan-keputusan untuk tidak bertindak, yang dibuat oleh badan atau kantor pemerintah". Kebijakan publik sesuai apa yang dikemukan oleh Dunn mengisyaratkan adanya pilihan-pilihan kolektif yang saling bergantung satu dengan yang lainnya, diaman didalamnya keputusan-keputusan untuk melakukan tindakan. Kebijakan publik yang dimaksud dibuat oleh badan atau kantor pemerintah . suatu Kebijakan publik apabila telah dibuat, maka harus diimplementasikan harus dilaksanakan oleh unit-unti adminitrasi yang memobilisasikan sumber daya finansial dan manusia, serta dievaluasikan 
agar dapat dijadikan sebagai mekanisme pengawasan terhadap kebijakan tersebut sesuai dengan tujuan kebijakan itu sendiri.

Menurut Dye dalam Rusli (2013:35) mendefinisikan kebijakan publik sebagai berikut: "Whatever government choose to do or not". ("Apapun yang dipilih pemerintah untuk dilakukan ataupun tidak dilakukan"). Menurut Freidrich dalam Rusli (2013:41) mendifinisikan kebijakan sebagai berikut: "Suatu arah tindakan yang diusulkan oleh seseorang, golongan atau pemerintah dalam suatu lingkungan tertentu yang memberikan hambatanhambatan dan dalam kesempatannya, yang diharapkan dapat memenuhi dan mengatasi halangan tersebut dalam rangka mencapai suatu tujuan tertentu". Berdasarkan definisi dan pendapat para ahli di atas, maka dapat dikemukakan bahawa kebijkan publik merupakan tindakan-tindakan tertentu yang dilakukan oleh pemerintah ataupun pejabat pemerintah. Setiap kebijakan yang dibuat oleh pemerintah pasti memiliki suatu tujuan, sehingga kebijakan publik berguna untuk memecahkan masalah atau problem yang ada dalam kehidupan masyarakat. Kebijakan publik sangat perlu adanya karena tugas pemerintah sebagai pelayanan masyarakat yang harus merumuskan tindakan-tindakan untuk masyarakat.

\section{b. Implementasi Kebijakan}

Implementasi kebijakan dalam artian luas dipandang sebagai alat administrasi hukum dimana berbagai sistem, organisasi prosedur dan teknik yang bekerja bersama-sama untuk menjalankan kebijakan guna meraih dampak atau tujuan yang diinginkan. Implementasi pada sisi yang lain merupakan fenomena yang kompleks yang mungkin dapat dipahami sebagai proses, keluaran dan sebagai hasil (Winarno, 2002: 101). Van Meter dan Van Horn (dalam Agustino, 2008: 139) menyebutkan implementasi kebijakan sebagai tindakan-tindakan yang dilakukan oleh individu-individu (kelompok-kelompok) pemerintah maupun swasta yang diarahkan untuk mencapai tujuan-tujuan yang telah ditetapkan dalam keputusan-keputusan kebijakan sebelumnya. Menurut Jones (dalam Tangkilisan, 2003: 17) terdapat tiga kegiatan utama yang paling penting dalam implementasi yaitu: 1) Penafsiran: yaitu kegiatan yang menerjemahkan makna program kedalam pengaturan yang dapat diterima dan dapat dijalankan; 2) Organisasi: yaitu unit atau wadah untuk menempatkan program kedalam tujuan kebijakan; dan 3) Penerapan: yaitu berhubungan dengan perlengkapan rutin bagi pelayanan, upah dan lainnya.

Mazmania dan Sabatier dalam Rusli (2013:87), mendefinisikan implementasi kebijakan sebagai: "Pelaksanaan keputusan kebijakan dasar, biasanya dalam bentuk undang-undang, namun dapat pula dalam bentuk perintah-perintah atau keputsan-keputusan eksekutif yang penting atau keputusan badan peradilan. Lazimnya, keptusan tersebut mendifinisikan masalah yang ingin diatasi, menyebutkan secara tegas tujuan atau saran yang ingin dicapai, dan berbagai cara untuk menstrukturkan atau mengatur proses implementasinya". 
Berdasarkan definisi di atas bahwa implementasi kebijakan merupakan tindakan-tindakan yang dilakukan oleh pemerintah untuk mencapai tujuan yang telah ditetapkan dalam suatu keputusan kebijakan. Akan tetapi pemerintah dalam membuat kebijakan juga harus mengkaji terlebih dahulu apakah kebijakan tersebut dapat memberikan dampak yang buruk atau tidak bagi masyrakat.

Seberapa baiknya suatu kebijakan kalau tidak dipersiapkan dan direncanakan dengan baik implementasinya maka apa yang menjadi tujuan kebijakan publik tidak akan terwujud. Begitu pula sebaliknya, sebaik apapun persiapan dan perencanaan implementasi kebijakan apabila tidak diimplementasikan dengan baik oleh para pelaksana kebijakan apa yang menjadi tujuan kebijakan maka tidak bisa tercapai.

\section{c. Model Implementasi Kebijakan}

Model adalah sebuah kerangkan sederhana yang merupakan sebuah usaha untuk memudahkan penjelasan terhadap suatu fenomena (Indiahono, 2009: 19). Pada prinsipnya terdapat dua pemilihan jenis model implementasi kebijakan public yaitu implementasi kebijakan publik yang berpola dari atas kebawah (top-down) dan dari bawah ke atas (buttom-up), serta pemilihan implementasi kebijakan publik yang berpola paksa (command and control) dan pola pasar (economic incentive) (Nugroho, 2003:167). Maka untuk melihat bagaimana proses implementasi kebijakan publik yang berpola dari atas kebawah (top-dwon) dapat berlangsung secara efektif, dapat diketahui dari berbagai model implementasi diantaranya model Van Meter dan Van Horn (dalam Winarno, 2002: 103) beranjak dari suatu argument bahwa perbedaanperbedaan dalam proses implementasi akan dipengaruhi oleh sifat kebijakan yang akan dilaksanakan. Selanjutnya Van Meter dan Van Horn menawarkan suatu pendekatan yang mencoba untuk menghubungkan antara isu kebijakan dengan implementasi, dan suatu model konseptual yang menghubungkan kebijakan dengan kinerja kebijakan. Mereka menegaskan bahwa perubahan, kontrol dan kepatuhan bertindak merupakan konsep-konsep penting dalam prosedur implementasi.

Dengan memanfaat konsep-konsep tersebut maka permasalahan yang perlu dikaji dalam hubungan ini adalah: a ) Hambatan-hambatan apakah yang terjadi dalam mengenalkan perubahan dalam organisasi; b) Seberapa jauhkah tingkat efektivitas mekanisme-mekanisme kontrol pada setiap jenjang struktur, masalah ini menyangkut kekuasaan dari pihak yang paling rendah dalam organisasi yang bersangkutan; dan c) Seberapa pentingkah rasa keterkaitan masing-masing orang dalam organisasi (masalah kepatuhan). Dari pandangan tersebut maka Van Meter dan Van Horn membuat tipologi kebijakan menurut: a) Jumlah masing-masing perubahan yang akan terjadi. B) Jangkauan atau lingkup kesepakatan terhadap tujuan diantara pihak-pihak yang terlibat dalam proses implementasi; dan c) Alasan dikemukakannya hal ini bahwa proses implementasi itu akan dipengaruhi oleh dimensi-dimensi kebijakan semacam itu, dalam artian bahwa implementasi akan berhasil apabila perubahan yang dikehendaki relatif seidkit sementara kesepakatan 
terhadap tujuan terutama dari para implementor dilapangan relatif tinggi. Hal ini yang dikemukakan mereka bahwa yang menghubungkan kebijakan dan kinerja dipisahkan oleh sejumlah variabel bebas yang saling berkaitan. Variabel tersebut dijelaskan sebagai berikut (dalam Winarno, 2002: 110):

1) Sasaran Kebijakan (ukuran dasar dan tujuan kebijakan)

2) Variabel ini didasarkan pada kepentingan utama terhadap sistem-sistem yang menentukan pencapaian kebijakan. Pencapaian ini menilai sejauh mana ukuran-ukuran dasar dan tujuan-tujuan kebijakan telah direalisasikan. Ukuran-ukuran dasar dan tujuan-tujuan berguna dalam menguraikan tujuan-tujuan keputusan kebijakan secara musyawarah.

3) Sumber Daya (sumber-sumber kebijakan)

4) Sumber-sumber layak mendapat perhatian karena menunjang keberhasilan implementasi kebijakan. Sumber-sumber yang dimaksud mencakup dana atau perangsang (incentive) lain yang mendorong dan memperlancar implementasi yang efektif, serta siapa yang melaksanakan program.

5) Komunikasi (komunikasi antar organisasi dan kegiatan-kegiatan)

6) Komunikasi antar oraganisasi-organisasi merupakan suatu proses yang kompleks dan sulit. Dalam menruskan pesan-pesan kedalam suatu organisasi ke organisasi lainnya, para komunikator dapat menyimpannya atau menyebarluaskan informasi, baik secar sengaja atau tidak sengaja. Lebih dari itu, jika sumber-sumber informasi yang berbeda memberikan interpretasi-interpretasi yang tidak konsisten terhadap ukuran-ukuran dasar dan tujuan-tujuan, serta jika sumber-sumber yang sama memberikan interpretasi-interpretasi yang bertentangan, para pelaksana akan menghadapi kesulitan yang lebih besar untuk melaksanakan maksud-maksud kebijakan.

7) Karakteristik Agen Pelaksana (badan-badan pelaksana)

8) Pusat perhatian pada agen pelaksana meliputi organisasi formal dan informal yang mencakup struktur birokrasi, norma-norma dan pola-pola hubungan yang terjadi. Hal ini sangat penting karena kinerja kebijakan publik akan sangat banyak dipengaruhi oleh cir-ciri kebijakan yang tepat serta cocok dengan para agen pelaksananya. Selain itu, cakupan atau luas wilayah implementasi kebijakan perlu juga diperhitungkan manakala hendak menentukan agen pelaksana. Semakin luas cakupan implementasi kebijakan, maka seharusnya semakin besar pula agen pelaksana yang terlibat didalamnya.

9) Kondisi Sosial dan Ekonomi

10) Variabel ini mencakup sumber daya ekonomi, lingkungan yang dapat mendukung keberhasilan implementasi kebijakan, sejauh mana kelompok-kelompok kepentingan dapat memberikan dukungan bagi implementasi kebijakan, karakteristik para partisipan yakni menolak atau mendukung, melihat bagaimana sifat opini publik yang ada dilingkungan dan apakah elit politik mendukung implementasi kebijakan.

11) Disposisi (sikap para pelaksana) 
12) Pada tahap ini pengalaman-pengalaman subjektivitas individu-individu memegang peranan penting. Van Metet dan Van Horn mengidentifikasikan tiga unsur tanggapan pelaksana yang mungkin mempengaruhi kemampuan dan keinginan mereka untuk melaksanakan kebijakan yakni: a. respon implementor terhadap kebijakan yang akan dipengaruhi kemampuannya untuk melaksanakan kebijakan, b. kognisi (pemahaman) para agen pelaksana terhadap kebijakan, c. intensitas disposisi implementor yakni prefensi nilai yang dimiliki oleh implementor.

\section{Metode Penelitian}

Pendekatan yang di gunakan dalam penelitian ini adalah pendekatan kualitatif. Metode penelitian kualitatif digunakan untuk mendapatkan data yang mendalam, suatu data yang mengandung makna atau data yang sebenarnya. Penelitian kualitatif tidak semena-mena mencari kebenaran, tetapi pada pemahaman terhadap apa yang di teliti. Menurut Creswell dalam Satori dan Komariah (2010:24), bahwa penelitian kualitatif adalah suatu proses inquiry tentang pemahaman berdasar pada tradisi-tradisi metodologis terpisah, jelas pemeriksaan bahwa menjelajah suatu masalah social atau manusia. Peneliti membangun suatu kompleks, gambaran, holistic, meneliti kata-kata, laporan,-laporan memerinci pandangan-pandangan dari penutur asli, dan melakukan studi di suatu pengaturan yang alami.

\section{Hasil dan Pembahasan}

\section{a. Bantuan Pangan Non Tunai}

Program Bantuan Pangan Non Tunai merupakan upaya mereformasi Program Subsidi Rastra yang dilaksanakan berdasarkan arahan Preseiden Republik Indonesia untuk meningkatkan efektifitas dan ketepatan sasaran program, serta mendorong inklusi keuangan. Penyaluran Bantuan Pangan secara Non Tunai dilaksanakan secara bertahap mulai tahun 2017 pada beberapa daerah terpilih di Indonesia dengan akses dan fasilitas memadai. Selain untuk memberikan pilihan pangan yang lebih luas, penyaluran Bantuan Pangan secara Non Tunai melalui sistem perbankan juga dimaksudkan untuk mendukung perilaku produktif masyarakat melalui fleksibilitas waktu penarikan bantuan dan akumulasi asset melalui kesempatan menabung. Pada akhirnya, penyaluran Bantuan Pangan Non Tunai diharapkan memberi dampak bagi peningkatan kesejahteraan dan kemampuan ekonomi penerima manfaat melalui akses yang lebih luas terhadap pelayanan keuangan. Bantuan Pangan Non Tunai adalah bantuan pangan dari pemerintah yang diberikan kepada KPM setiap bulannya melalui Mekanisme akun Elektronik yang digunakan hanya untuk membeli pangan di e-Warong/pedagang bahan pangan yang bekerja sama dengan Bank 
Himbara. Bertujuan untuk mengurangi beban pengeluaran serta memberikan nutrisi yang lebih seimbang kepada KPM secara tepat sasaran dan tepat waktu. Setiap Keluarga Penerima Manfaat (KPM), mendapatkan bantuan sosial sebesar $\mathrm{Rp} 110.000 \mathrm{ribu}$, yang ditransfer setiap bulannnya melalui Kartu Keluarga Sejahtera (KKS) elektronik. Dengan adanya KKS, peserta KPM dapat membeli kebutuhan bahan pangan seperti (beras, gula, tepung, minyak goreng dan lain-lain), melalui agen yang tersedia di beberapa lokasi tertentu. Program Bantuan Pangan Non Tunai merupakan suatu upaya pemerintah untuk membantu mengurangi beban pengeluaran penduduk miskin. Melalui program tersebut yang diharapkan dapat memberikan manfaat yang nyata dalam perubahan pola pengeluaran rumah tangga yaitu dengan peningkatan konsumsi pangan maupun non pangan rumah tangga. Salah satu kebijakan yang ditetapkan oleh pemerintah adalah kebijakan beras untuk keluarga miskin. Koutsoyianis (1975) berpendapat subsidi bahan pangan kepada penduduk miskin akan meningkatkan kesejahteraan penerima subsidi.

Program Bantuan Pangan Non Tunai ini diasumsikan akan dapat mempengaruhi pola pengeluaran rumah tangga. Penyaluran beras bersubsidi bagi kelompok masyarakat berpendapatan rendah bertujuan untuk mengurangi beban pengeluaran para rumah tangga penerima bantuan pangan dalam memenuhi kebutuhan pangan. Selain itu juga untuk meningkatkan akses masyarakat berpendapatan rendah dalam pemenuhan kebutuhan pangan pokok, sebagai salah satu hak dasarnya. Negara Indonesia menyalurkan bantuan sosial dengan menggunakan sistem non tunai, sebagai contoh dalam penyaluran bahan-bahan kebutuhan sehari-hari, yang disebut bantuan pangan non tunai. Hal ini dimaksudkan untuk meningkatkan efektivitas bantuan sosial, ketepatan sasaran serta untuk mendorong keuangan inklusif. Melalui penyaluran bantuan sosial non tunai dengan menggunakan sistem perbankan, diharapkan dapat mendukung perilaku produktif penerima bantuan, serta meningkatnya transparansi dan akuntabilitas program untuk kemudahan dalam mengontrol, memantau dan mengurangi penyimpangan.

\section{b. Elektronik Warung Gotong Royong}

Elektornik Warung Gotong Royong atau E-Warong yang merupakan salah satu pengembangan program dari Kelompok Usaha Bersama (KUBE) dan Program Keluarga Harapan (PKH) yang dapat dikategorikan sebagai Program Bantuan Non Tunai. Program Bantuan Non Tunai merupakan upaya mereformasi Program Subsidi Rastra yang dilaksanakan berdasarkan arahan Presiden Republik Indonesia untuk meningkatkan efektifitas dan ketepatan sasaran program, serta mendorong inklusi keuangan. Dalam Pedoman Pelaksanaan Bantuan Pangan Non Tunai (2016:4) dinyatakan bahwa : "Bantuan Pangan Non Tunai adalah bantuan sosial pangan dalam bentuk non tunai dari pemerintah yang diberikan kepada KPM (Keluarga Penerima Manfaat) setiap bulannya melalui mekanisme akun elektronik yang digunakan hanya untuk membeli bahan pangan di pedagang bahan 
pangan e-warong yang bekerjasama dengan bank". Penyaluran Bantuan Pangan Non Tunai dilaksanakan melalui sistem perbankan untuk mendukung perilaku produktif masyarakat melalui fleksibilitas waktu penarikan bantuan dan akumulasi aset melalui kesempatan menabung. Pada akhirnya,penyaluran Bantuan Pangan Non Tunai diharapkan memberi dampak bagi peningkatan kesejahteraan dan kemampuan ekonomi penerima manfaat melalui akses yang lebih luas terhadap layanan keuangan. Pelaksanaan penyaluran Bantuan Pangan Non Tunai dibantu oleh perbankan yang menjadi agen penyalur bantuan. Dalam pedoman pelaksanaan Bantuan Pangan Non Tunai (2016:4) dijelaskan bahwa "Bank Penyalur Bantuan Pangan Non Tunai adalah bank mitra kerja Pemerintah yang menyalurkan dana bantuan pangan kepada Keluarga Penerima Manfaat (KPM) secara non tunai".

Pemberian Bantuan Pangan Non Tunai diberikan kepada KPM melalui Kartu Kombo yang merupakan instrumen pembayaran yang memiliki fitur uang elektronik dan tabungan yang digunakan sebagai media penyaluran bantuan sosial. Bahan pangan yang disalurkan kepada KPM adalah beras dan telur. Proses konversi Bantuan Pangan Non Tunai dilakukan di e-Warong atau agen penyalur. Dalam Petunjuk Teknik Pelaksanaan Bantuan Pangan Non Tunai (2016:5) ditentukan bahwa : "e-Warong adalah istilah yang digunakan dalam Program Bantuan Non Tunai yang menyebutkan agen bank. Pedagangan dan atau pihak lain yang telah bekerja sama dengan Bank Penyalur dan ditentukan sebagai tempat pembelian bahan pangan oleh KPM, yaitu pasar tradisional, warung, toko kelontongan, e-Warong KUBE, Warung Desa, Rumah Pangan Kita (RPK), Agen laku Pandai, Agen Layanan Keuangan Digital (LKD) yang menjual bahan pangan, atau usaha eceran lainnya". Penyaluran Bantuan Pangan Non Tunai yang dilakukan oleh agen e-Warong kepada Keluarga Penerima Manfaat yang telah terverifikasi sebagai penerima bantuan pangan non tunai dan telah memiliki kartu kombo.

\section{c. Implementasi Kebijakan Bantuan Pangan Non Tunai Melalui Elektronik Warung Gotong Royong (E-Warong)}

Implementasi kebijakan ini merupakan tahapan penting dalam suatu kebijakan, tanpa adanya implementasi maka suatu kebijakan tersebut hanya akan menjadi suatu impian atau rencana yang bagus yang tersimpan rapi dalam arsip (Wahab, 2008: 64). Pada tahapan implementasi, tentunya akan ditemukan variabel-variabel yang mempengaruhi keberhasilan ataupun kegagalan sebuah implementasi kebijakan. Untuk itu dalam penelitian ini peneliti mencoba untuk menganalisis data yang berkaitan dengan proses implementasi kebijakan Bantuan Pangan Non Tunai melalui Elektronik Warung Gotong Royong (E-Warong) di Kecamatan Subang baik itu yang diperoleh melalui wawancara, observasi, dokumentasi dan kepustakaan terhadap fenomena fenomena yang ada di lapangan.

Dalam hal ini peneliti menggunakan model implementasi kebijakan dari Van Meter dan Van Horn. Model ini dipilih karena variabel-variabel dari model implementasi ini dapat menjelaskan secara komprehensif tentang proses 
implementasi kebijakan Bantuan Pangan Non Tunai melalui Elektronik Warung Gotong Royong (E-Warong) di Kecamatan Subang. Adapun variabelvariabel dari model implementasi ini adalah: sasaran kebijakan, sumber daya, komunikasi, karakteristik agen pelaksana, kondisi sosial dan ekonomi serta disposisi.

\section{c.1 Sasaran Kebijakan (ukuran dasar dan tujuan kebijakan)}

Menurut Van Meter dan Van Horn dalam Subarsono (2013:99) standar dan sasaran kebijakan harus jelas dan terukur sehingga dapat direalisi. Apabila standar dan sasaran kebijakan kabur, maka akan terjadi multiinterpretasi dan mudah. Sasaran kebijakan pada dasarnya adalah apa yang hendak dicapai oleh program atau kebijakan baik yang berwujud maupun tidak serta didasarkan pada kepentingan utama terhadap sistem-sistem yang menentukan pencapaian kebijakan. Standar dan sasaran kebijakan harus jelas dan terukur sehingga dapat direalisir. Apabila standar dan sasaran kebijakan kabur, maka akan terjadi multiinterpretasi dan mudah menimbulkan konflik diantara para agen implementasi (dalam Subarsono 2005: 99). Dalam proses pencapaian sasaran kebijakan akan menilai sejauhmana ukuran dasar dan tujuan kebijakan yang telah direalisasikan. Dalam penelitian ini sasaran kebijakan Bantuan Pangan Non Tunai melalui Elektronik Warung Gotong Royong (E-Warong) di Kecamatan Subang ini dapat dilihat dari beberapa hal yaitu proses tahapan pelaksana, kesesuaian bantuan yang diterima serta manfaat program yang dibuat. Maka dari itu peneliti menemukan temuan mengenai sasaran kebijakan Bantuan Pangan Non Tunai melaui Elektronik Warung Gotong Royong (E-Warong). Peneliti melakukan wawancara dengan Kasi Kesejahteraan Sosial Kecamatan Subang sebagai pelaksana kebijakan Bantuan Pangan Non Tunai melalui E-Warong di tingkat Kecamatan. Beliau mengatakan : "Saya paham mengenai sasaran kebijakan ini. Sebetulnya tujuan BPNT melalui EWarong itu bantuan yang diberikan oleh pemerintah kepada masyarakat tidak mampu secara non tunai dan E-Warong sebagai sarana pelayanan transaksi keuangan secara elektronik dengan memberdayakan Keluarga Penerima Manfaat sebagai pengelola E-Warong. Nah sehingga dapat mengembangkan kemampuannya dalam berwirausaha. Tetapi di Kecamatan Subang, pemilihan E-Warong itu masih mengambil dari agenbrilink yang sudah ada". Ungkapan di atas dapat memberi penjelasan bahwa para pelaksana kebijakan sudah memahami apa yang menjadi sasaran kebijakan. Bahwa yang menjadi sasaran dari kebijakan ini adalah masyarakat tidak mampu (miskin). Akan tetapi dalam menentukan pengelola E-Warong belum tepat sasaran. Hal ini terjadi karena kurangnya koordinasi antar agen pelaksana kebijakan. Agar lebih jelas dalam penelitian ini, maka peneliti melakukan wawancara kembali dengan Tenaga Kesejahteraan Sosial Kecamatan Subang. Beliau mengatakan : “Dengan adanya program Bantuan Pangan Non Tunai melalui E-Warong kan dapat mempercepat peningkatan ekonomi 
penerima bantuan, di mana Keluarga Penerima Manfaat (KPM) diberdayakan untuk kemudian ditunjuk membuat E-Warong di lokasi yg sudah ditentukan, yang nantinya mereka diberdayakan sebagai penyalur bantuan-bantuan sosial yang tentunya non tunai, namun EWarong di Kecamatan Subang belum sesuai dengan kriteria, karena pemilik E-Warong bukan bersal dari Keluarga Penerima Manfaat melainkan berasal dari agenbrilink". Berdasarkan uraian di atas diketahui bahwa para pelaksana kebijakan sudah memahami standar dan sasaran dari kebijakan ini. Namun ketika berbicara sasaran kebijakan, para pelaksana belum mencapai sasaran dari kebijakan ini. Hal ini terbukti bahwa pemilik E-Warong bukan berasal dari Keluarga Penerima Manfaat bantuan sosial. Terjadinya permasalahan ini disebabkan kurangnya komunikasi antar pelaksana kebijakan dalam menyiapkan E-Warong. Berdasarkan hasil kajian mendalam dari hasil wawancara dengan beberapa informan, dapat disimpulkan bahwa sumber daya manusia dalam mengimplementasikan kebijakan Bantuan Pangan Non Tunai melalui Elektronik Warung Gotong Royong (EWarong) di Kecamatan Subang sudah optimal dan memberikan pelayanan yang baik terhadap Keluarga Penerima Manfaat (KPM).

\section{c.2 Sumber Daya Modal (Sarana dan Prasarana)}

Secara umum sarana dan prasarana adalah alat penunjang keberhasilan suatu proses upaya yang dilakukan didalam pelayanan publik, karena apabila kedua hal ini tidak tersedia maka semua kegiatan yang dilakukan tidak akan dapat mencapai hasil yang diharapkan sesuai dengan rencana. Dalam hal sarana dan prasarana yang berkaitan dengan implementasi kebijakan Bantuan Pangan Non Tunai melalui E-Warong, peneliti melakukan wawancara dengan Kasi Kesejahteraan Sosial Kecamatan Subang. Beliau mengatakan bahwa : "Sarana dan prasarana untuk mengimplementasikan kebijakan ini belum cukup memadai untuk saat ini. E-Warong di Kecamatan Subang masih perlu ditambahkan jumlahnya. Karena E-Warong menjadi sarana dan prasarana dalam penyaluran bantuan".

Pernyataan di atas menjelaskan bahwa sarana dan prasarana untuk menjalankan kebijakan ini belum cukup memadai, terbukti jumlah EWarong yang ada di Kecamatan Subang sebagai sarana dan prasarana untuk menjalankan kebijakan ini masih kurang. Selanjutnya hal senada juga diungkapkan oleh Tenaga Kesejahteraan Sosial Kecamatan Subang, beliau mengatakan : "Kita sebagai pelaksana merasa kekurangan untuk hal sarana dan prasarana. E-Warong yang ada di Kecamatan Subang berjumlah 23. Untuk rencana kedepan kita akan memperbanyak EWarong agar tidak terjadi penumpukan KPM lagi di 10 E-Warong pada saat penyaluran bantuan". Ungkapan di tersebut menjelaskan bahwa kelengkapan sarana dan prasarana masih belum memadai dan menghambat pada pengimplementasian kebijakan Bantuan Pangan Non Tunai melalui E-Warong. Agen pelaksana merasa masih perlu 
penambahan E-Warong sebagai sarana dan prasarana dalam kebijakan ini.

Penulis menganalisa hasil dari wawancara diatas, diketahui bahwa mengenai sarana dan prasarana semua informan memberikan tanggapan yang kurang baik. Hal ini masih perlu perbaikan lagi, karena tidak sesuai dengan teori yang dikemukakan oleh Van Meter dan Van Horn dalam Subarsono (2013:100) bahwa keberhasilan proses implementasi kebijakan sangat tergantung dari kemampuan memanfaatkan sumber daya yang tersedia. Tersedianya sumber daya yang dibutuhkan itu menunjang keberhasilan kebijakan, yang harus ditegaskan adalah sumber daya yang cukup dan terpakai atau bermanfaat sehingga tidak terjadi pemborosan anggaran.

\section{c.3 Komunikasi (komunikasi antar organisasi dan kegiatan-kegiatan)}

Pentingnya kerjasama dan komunikasi antar organisasi adalah untuk mencapai tujuan dengan hasil yang memuaskan dan sesuai dengan apa yang diharapkan dari suatu kebijakan. Kerjasama dan komunikasi tidak dapat berjalan sendiri-sendiri melainkan dua hal ini dapat menjadikan sebuah kebijakan berjalan efektif tatkala terdapat sebuah kerjasama dapat berjalan secara bersamaan. Kebijakan kadangkala tidak dapat diimplementasikan secara efektif bukan lantaran ia telah diimplementasikan secara kurang baik, melainkan karena kebijaksanaan itu sendiri memang belum terarah. Penyebab dari semua ini tidak lain karena kebijkasanaan itu didasari oleh tingkat pemahaman yang tidak memadai mengenai persoalan yang akan ditanggulangi sebab-sebab timbulnya masalah dan cara pemecahannya. Kebijakankebijakan yang berhubungan sebab akibatnya tergantung pada mata rantai yang amat panjang maka ia akan mudah sekali mengalami keretakan, sebab semakin panjang mata rantai maka semakin besar hubungan timbal balik diantara mata rantai penghubungnya dan semakin menjadi kompleks implementasinya (Nugroho, 2004:34).

Berdasarkan hasil kajian serta hasil wawancara di atas menjelaskan bahwa komunikasi antar organisasi yaitu Kecamatan Subang dengan Dinas Sosial dalam pemilihan Elektronik Warung Gotong Royong (EWarong) belum berjalan optimal. Kurangnya hubungan antar organisasi tersebut menimbulkan permasalahan yang berpengaruh sangat besar terhadap keberhasilan implementasi kebijakan Bantuan Pangan Non Tunai Melalui E-Warong. Hasil wawancara di atas menjelaskan bahwa masyarakat penerima Bantuan Pangan Non Tunai tidak mengetahui komunikasi yang dilakukan dalam mengimplementasikan kebijakan ini. Mereka hanya mengetahui bahwa mereka menerima bantuan rutin setiap bulannya. Masyarakat penerima Bantuan Pangan Non Tunai tidak mengetahui komunikasi yang dilakukan. Akan tetapi masyarakat menyimpulkan bahwa komunikasi yang dilakukan belum berjalan baik. Masyarakat melihat fenomena yang ada di lapangan bahwa dalam 
pengambilan Bantuan Pangan Non Tunai selalu terjadi penumpukan hingga 300 orang lebih. Hal tersebut jelas menyalahi aturan yang ada.

\section{c.4 Karakteristik Agen Pelaksana (badan-badan pelaksana)}

Karakteristik dari agen pelaksana menjadi salah satu perhatian pusat. Pada agen pelaksana meliputi organisasi informal yang akan terlibat dalam pengimplementasian kebijakan publik. Hal ini sangat penting karena kinerja implementasi kebijakan (publik) akan sangat banyak dipengaruhi oleh ciri-ciri yang tepat serta cocok dengan para agen pelaksananya.

Hasil wawancara di atas menjelaskan bahwa agen pelaksana kebijakan memiliki karakteristik yang baik dan perhatian terhadap masyarakat yang merupakan sasaran dari kebijakan Bantuan Pangan Non Tunai melalui E-Warong. Hal ini sudah seharusnya dilakukan oleh agen pelaksana kebijakan untuk mencapai keberhasilan implementasi kebijakan Bantuan Pangan Non Tunai melalui Elektronik Warung Gotong Royong (E-Warong) di Kecamatan Subang. Selanjutnya peneliti melakukan wawancara dengan Tenaga Kesejahteraan Sosial Kecamatan Subang. Beliau mengatakan : "Saya selaku pendamping BPNT selalu memberikan perhatian kepada KPM yang tidak mengerti dalam mengambil bantuan melalui E-Warong. KPM dibimbing dalam melakukan transaksi secara non tunai di E-Warong hingga para KPM bisa melakukannya sendiri". Ungkapan di atas menjelaskan bahwa para pelaksana kebijakan memiliki karakteristik yang baik dan sesuai peraturan yang ada, serta memberikan kemudahan kepada masyarakat penerima Bantuan Pangan Non Tunai melalui E-Warong. Karakteristik agen pelaksana yang baik dapat menyelesaikan permasalahan dengan cepat, serta bisa memberikan kepuasan kepada KPM sesuai dengan apa yang dibutuhkan oleh KPM. Karakteristik inilah yang sangat penting untuk mencapai keberhasilan implementasi suatu kebijakan.

Dari hasil wawancara tersebut dapat diketahui bahwa agen pelaksana kebijakan Bantuan Pangan Non Tunai melalui E-Warong dilihat dari kinerja dan prosedur pelayanan kepada masyarakat sudah optimal. Konsistensi perilaku implementor dari tingkat pemimpin teratas sampai pelaksana harus ditingkatkan dalam mengimplementasikan kebijakan sesuai dengan tujuan kebijakan yang telah ditentukan. Diyakini bahwa dengan adanya konsistensi sikap implementor dari mulai proses perencanaan sampai dengan proses pengawasan akan sangat memberikan kontribusi terhadap keberhasilan implmentasi kebijakan Bantuan Pangan Non Tunai melalui Elektronik Warung Gotong Royong (E-Warong) di Kecamatan Subang.

\section{c.5 Kondisi Sosial dan Ekonomi}

Lingkungan sosial dan ekonomi ini sebenarnya menunjuk kondisi atau keadaan lingkungan dalam ranah implementasi dapat mempengaruhi kesuksesan implementasi kebijakan itu sendiri. Dalam 
hal ini menilai sejauh mana lingkungan eksternal turut mendorong keberhasilan kebijakan publik. Lingkungan sosial dan ekonomi yang tidak kondusif dapat menjadi menjadi sumber masalah dari kegagalan kinerja implementasi kebijakan. Karena itu, upaya implementasi kebijakan mensyaratkan kondisi lingkungan eksternal yang kondusif. Sekalipun dampak dari sistem-sistem ini pada implementasi keputusankeputusan kebijakan mendapat perhatian yang kecil, sistem-sistem ini mungkin mempunyai efek mendalam terhadap pencapaian badanbadan pelaksana.

Peneliti melakukan wawancara dengan Kasi Kesejahteraan Sosial Kecamatan Subang, beliau mengatakan : "Pasti kondisi sosial dan ekonomi sangat berpengaruh terhadap keberhasilan program BPNT melalui E-Warong. Karena tingkat kemiskinan serta rendahnya pendidikan masyarakat berdampak terhadap pengetahuan kebijakan BPNT melalui E-Warong. Maka dari itu kita sebagai pelaksana kebijakan berusaha menangani permasalahan ini. Tindakan yang sudah dilakukan adalah melakukan sosialisasi kepada masyarakat mengenai kebijakan BPNT yg disalurkan melalui E-Warong ini. Sosialisasi ini dilakukan agar masyarakat penerima bantuan benar-benar paham terhadap mekanisme pengambilan bantuan secara non tunai yang dilakukan di E-Warong. Tetapi kegiatan sosialisasi ini belum kita lakukan secara rutin. Saya tidak mengetahui aturan berapakali sosialisasi ini harus dilakukan".

Berdasarkan uraian di atas diketahui bahwa Kecamatan Subang dalam upaya mencapai keberhasilan implementasi kebijakan Bantuan Pangan Non Tunai melalui E-Warong sudah berusaha melakukan sosialisasi kepada masyarakat terkait kebijakan tersebut. Kegiatan sosialisasi ini sangat perlu dilakukan guna mengetahui hambatanhambatan apa saja yang terjadi dan bagaimana solusinya, sehingga kebijakan tersebut akan optimal. Namun pelaksanaan sosialisasi ini belum dilakukan secara optimal oleh agen pelaksana kebijakan. Berdasarkan keterangan tersebut maka penulis mengkategorikan bahwa pelaksanaan sosialisasi kepada masyarakat penerima Bantuan Pangan Non Tunai di Kecamatan Subang belum optimal. Ungkapan di atas menjelaskan bahwa pelaksana kebijakan Bantuan Pangan Non Tunai melalui E-Warong dalam pelaksanaannya mengenai kebijakan tersebut belum optimal. Fenomena yang terjadi di lapangan menunjukkan bahwa masyarakat masih belum paham dalam mekanisme cara pengambilan bantuan secara non tunai yang dilakukan di E-Warong. Hal ini harus menjadi perhatian untuk agen pelaksana guna mencapai keberhasilan implementasi kebijakan Bantuan Pangan Non Tunai melalui Elektronik Warung Gotong Royong (E-Warong) di Kecamatan Subang.

\section{c.6 Disposisi (sikap para pelaksana)}

Disposisi atau sikap pelaksana yaitu kecenderungan para pelaksana menunjuk pada karakteristik yang menempel erat pada implementor kebijakan atau program. Sikap para implementor sangat dibutuhkan 
dalam menjalankan sebuah kebijakan. Dalam proses implementasi kebijakan kita harus bisa melihat seberapa besar kekuasaan dari pembuat kebijakan dan pelaksana program kebijakan sehingga semakin jelas tujuan yang ingin dicapai. Hanya saja jika semakin besar kepentingan yang mempengaruhi maka akan sedikit susah untuk mengimplementasikan kebijakan.

Selain itu seorang implementor harus bisa merencanakan strategi yang akan digunakan untuk mengimplementasikan kebijakan. Sikap penerimaan atau penolakan dari agen pelaksana kebijakan sangat mempengaruhi keberhasilan atau kegagalan implementasi kebijakan publik. Kebijakan publik biasanya bersifat top down yang sangat mungkin para pengambil keputusan tidak mengetahui bahkan tak mampu menyentuh kebutuhan, keinginan atau permasalahan yang harus diselesaikan. Maka gambaran omitmen dan kejujuran sangat diperlukan untuk melihat konsistensi antara pelaksana kegiatan dengan agen yang ditunjuk.

Berdasarkan hasil wawancara diketahui bahwa disposisi atau sikap para pelaksana dalam mengimplementasikan kebijakan Bantuan Pangan Non Tunai melalui E-Warong sudah sesuai dengan kebijakan. Kemampuan para pelaksana untuk mencapai keberhasilan kebijakan ini sudah optimal. Sikap inilah yang sangat penting untuk mencapai keberhasilan suatu kebijakan. Selanjutnya peneliti melakukan wawancara dengan Tenaga Kesejahteraan Sosial Kecamatan Subang, beliau mengatakan: "Program BPNT yang disalurkan melalui E-Warong dalam melayani KPM cukup baik. Kita selalu memberikan arahan kepada KPM yang belum paham terhadap mekanisme transaksi yang dilakukan di E-Warong. Kami selalu berusaha memberi pendampingan kepada KPM yang belum mengerti".

Hasil penelitian tersebut penulis menarik kesimpulan bahwa secara umum petugas yang menjalankan kebijakan Bantuan Pangan Non Tunai melalui E-Warong sudah dirasakan baik oleh masyarakat penerima bantuan dan pemilik E-Warong. Namun masyarakat masih perlu pendampingan dari petugas ketika melakukan transaksi di E-Warong. Sehingga penulis dapat mengkategorikan disposisi sikap para pelaksana sudah optimal namun masih perlu adanya sosialisasi dan bimbingan yang lebih intensif kepada masyarakat yang masih belum paham.

\section{Kesimpulan}

Berdasarkan penelitian yang diperoleh, implementasi kebijakan Bantuan Pangan Non Tunai melalui Elektronik Warung Gotong Royong (E-Warong) di Kecamatan Subang dengan menggunakan teori Van Meter dan Van Horn ada beberapa indikator yang belum optimal dalam pelaksanaannya. Hal ini terlihat dalam teori implementasi kebijakan sebagai berikut : 
1) Sasaran Kebijakan (ukuran dasar dan tujuan kebijakan); Bahwa kebijakan Bantuan Pangan Non Tunai melalui Elektronik Warung Gotong Royong (E-Warong) adalah salah satu kebijakan pemerintah yang bertujuan untuk mengurangi beban dalam pemenuhan kebutuhan pokok berupa bahan pangan kepada mayarakat kurang mampu (miskin) yang disalurkan secara non tunai melalui mekanisme akun elektronik dengan mengoptimalkan E-Warong sebagai penyalur bantuan tersebut. Dalam mengimplementasikan kebijakan Bantuan Pangan Non Tunai melalui Elektronik Warung Gotong Royong (E-Warong) di Kecamatan Subang, agen pelaksana sudah memahami sasaran kebijakan ini dan manfaat dari adanya kebijakan ini sudah dirasakan oleh masyarakat. Akan tetapi kebijakan Bantuan Pangan Non Tunai melalui E-Warong dalam pelaksanaannya belum tepat sasaran dalam pemilihan pemilik E-Warong, Seluruh pemilik E-Warong di Kecamatan Subang bukan berasa dari penerima manfaat Bantuan Sosial melainkan berasal dari agenbrilink yang sudah ada.

2) Sumber Daya (sumber-sumber kebijakan); Dalam proses implementasi kebijakan Bantuan Pangan Non Tunai melalui Elektronik Warung Gotong Royong (E-Warong), dukungan sumber daya manusia sudah optimal. Hal ini dilihat dari pelaksana kebijakan yang paham dalam mengelola kebijakan ini. Selain sumber daya manusia, sumber daya sarana dan prasarana merupakan faktor keberhasilan implementasi kebijakan. Sarana dan prasarana dalam proses implementasi kebijakan Bantuan Pangan Non Tunai melalui Elektronik Warung Gotong Royong (E-Warong) di Kecamatan Subang masih belum optimal. Diketahui bahwa kelengkapan sarana dan prasarana masih belum memadai dan menghambat pada pengimplementasian kebijakan Bantuan Pangan Non Tunai melalui E-Warong. Masih perlu adanya penambahan E-Warong sebagai sarana dan prasarana dalam kebijakan ini, agar tidak terjadi penumpukan KPM di 10 E-Warong yang ada di Kecamatan Subang.

3) Komunikasi (komunikasi antar organisasi dan kegiatan kegiatan); Komunikasi antar organisasi dalam mewujudkan keberhasilan implementasi kebijakan Bantuan Pangan Non Tunai melalui Elektronik Warung Gotong Royong (E-Warong) belum optimal. Komunikasi antara Kecamatan Subang dengan Dinas Sosial dalam menentukan persyaratan dan kriteria E-Warong belum berjalan optimal. Hal ini sangat berdampak pada kegagalan dalam pencapaian target sasaran kebijakan.

4) Karakteristik Agen Pelaksana (badan-badan pelaksana); Karakteristik agen pelaksana dalam proses implementasi kebijakan Bantuan Pangan Non Tunai melalui Elektronik Warung Gotong Royong (E-Warong) di Kecamatan Subang sudah optimal dan dirasakan oleh masyarakat. Dalam memberikan pelayanan kepada masyarakat penerima bantuan sudah sesuai dengan prosedur yang ada. Akan tetapi perilaku agen pelaksana dalam pelayanan di Kelurahan belum ramah dan masih harus diperbaiki.

5) Kondisi Sosial dan Ekonomi; Implementasi tidak hanya melibatkan perilaku badan-badan administrative yang bertanggungjawab untuk 
melaksanakan kebijakan dan menimbulkkan ketaatan pada kelompok sasaran, tetapi juga menyangkut jaringan kekuatan sosial dan ekonomi. Kecamatan Subang sudah melakukan sosialisasi kepada masyarakat mengenai kebijakan Bantuan Pangan Non Tunai melalui Elektronik Warung Gotong Royong (E-Warong), dampak dari adanya sosialsiasi ini sangat baik. Masyarakat di ajari tentang transaksi secara non tunai di EWaong. Namun kegiatan sosialisasi ini pelaksanaannya belum optimal, karena masih ada masyarakat yang belum paham untuk melakukan transaksi pada saat pengambilan bantuan.

6) Disposisi (sikap para pelaksana); Sikap pelaksana kebijakan akan mempengaruhi berhasil atau tidaknya sebuah kebijakan, sikap ini tergantung dari bagaimana agen pelaksana kebijakan menanggapi sebuah kebijakan tersebut, mereka bisa saja mengerti atau memahami, bahkan kebalikannya. Dalam proses implementasi Kebijakan Bantuan Pangan Non Tunai melalui Elektronik Warung Gotong Royong (EWarong) para pelaksana kebijakan sudah menjalankan sesuai dengan kebijakan yang ada. Seperti pelayanan sudah optimal sehingga manyarakat merasa mudah dan mengerti ketika petugas melakukan pendampingan.

\section{Referensi}

Agustino, Leo. 2008. Dasar-Dasar Kebijakan Publik. Bandung: Alfabeta.

DeCenzo, David A, dan Stephen P Robbins. 2010. Fundamentals of Human Resources Management. USA: John Wiley \& Sons,Inc.

Indiahono, Dwiyanto. 2009. Kebijakan Publik Berbasis Dynamic Policy Analysis. Yogyakarta: Gava Media.

Moleong, 2007. Metode Penelitian Kualitatif. Bandung: PT. Remaja Rosada

Nugroho, Riant. 2014. Public policy. Jakarta: PT. Elex Media Komputindo

Pasolong, 2016. Metode penelitian administrasi public. Bandung: CV. Alfabeta

Peraturan Menteri Sosial Republik Indonesia Nomor 25 Tahun 2016 Tentang Bantuan Pengenbangan Sarana Usaha Melalui Elektronik Warung Gotong Royong Kelompok Usaha Bersama Program Keluarga Harapan

Peraturan Menteri Sosial Republik Indonesia Nomor 11 Tahun 2018 Tentang Penyaluran Bantuan Pangan Non Tunai

Rusli, Budiman. 2013. Kebijakan Publik. Membangun Pelayanan Publik yang Responsif. Bandung: Hakim Publisher.

Satori dan komariah, 2007. Metedologi penelitian kualitatif. Bandung: CV Alfabeta

Subarsono, AG. 2005. Analisis Kebijakan Publik. Yogyakarta: Pustaka Pelajar.

Sugiono, 2017. Metode Penelitian Kualitatif, Kualitatif RED. Bandung: CV. Alfabeta 
Tangkilisan, Hesel Nogi. 2003. Implementasi Kebijakan Publik: Transformasi Pikiran George Edward. Yogyakarta: Lukman Offset

Thoha, Miftah. 2010. Kepemimpinan Dalam Manajemen. Jakarta: PT. Raja Grafndo Persada.

Wahab, Solichin A. 2008. Pengantar Analisis Kebijakan. Malang: UMM Press.

Winarno, Budi. 2002. Teori dan Proses Kebijakan Publik. Yogyakarta: Media Pressindo. 